\title{
Accounting Information in a Business Decision-Making Process - Evidence from Croatia
}

\author{
Ana Ježovita*
}

\begin{abstract}
The objective of the conducted research includes examining importance of financial statements and financial statements analysis in business decision-making process. Conducted empirical research is focused on analysis of determining and evaluating the frequency of using accounting data and annual financial statements within the business decision-making process. According to obtained results, it can be concluded that more than $60 \%$ of examines frequently use accounting information and information available from annual financial statements within business decision-making process, and that they are familiar with methods of using technics of financial statements analysis for purposes of evaluating financial position and business efficiency.
\end{abstract}

Keywords: financial statements analysis, financial ratios, decision-making process, accounting information

JEL Classification: $\mathrm{M} 41$

\section{Introduction}

Making business decisions require having adequate, timely and comprehensive information, especially in contemporary business conditions characterized by globalization and rapid market changes. Information used within business decision process can be qualitative and quantitative. Additionally, quantitative information can be non-financial or financial. Sources of non-financial information are all organizational parts of the company, industry and economy. On the other hand, main source of financial information is company's accounting system. „Examples of quantitative financial factors include the cost of direct materials, direct manufacturing labour, and marketing. Other quantitative factors are non-financial; they can be measured numerically, but they are not expressed in monetary terms. Reduction

\footnotetext{
* Ana Ježovita is at Faculty of Economics and Business, University of Zagreb, Zagreb, Croatia.
} 
in new product-development time and the percentage of on-time flight arrivals are examples of quantitative non-financial factors. Qualitative factors are outcomes that are difficult to measure accurately in numerical terms“" (Horngren, et al., 2012, p. 394).

„Company, as an independent organizational unit, can be observed through three sub-systems including operating, information and managerial sub-system. Source of large number of extremely important quantitative and qualitative information, necessary for business decision making, is provided from information sub-system" (Dečman, et al., 2013, p. 40). ,Majority of information significant for a business decision making process is generated from accounting information system; therefore it is in the interest of the management to ensure their quality" (Oluić, 2008, p. 242). Even narrower, financial accounting represents crucial source of necessary information, especially from point of external users who use them in context of making decisions about investments or lending.

„Accounting ensures quantitative, primarily financial information, which are used within a business decision making process“ (Vitasović, 2012, p. 565). „The purpose of financial information is to provide inputs for decision making. Accounting is the information system that identifies, records, and communicates the economic events of an organization to interested users“ (Kimmel, et al., 2011, p. 5). „Management accounting measures, analyses, and reports financial and non-financial information that helps managers in making decisions to fulfil the goals of an organization. Managers use management accounting information to develop, communicate, and implement strategy. They also use management accounting information to coordinate product design, production, and marketing decisions and to evaluate performance" (Horngren, et al., 2012, p. 4).

Due to simplicity of calculation and application, individual financial ratios represents useful tool for evaluating business quality of the company. „Ratios are formed and calculated to create information basis necessary for making business decisions“ (Žager L., 2006, p. 16). According to Crosson \& Needles (2008) financial stetements analysis "plays a key role in all phases of the management process" (Crosson \& Needles, 2008, p. 658). In that context, important phases are planning, performing, evaluating and communicating about financial efficiency of the company. Reaching financial efficieny is directly related with creating value added which can be charaterized as the fundamental objective of a company's business. „A primary objective is to increase the wealth of the company's stockholders, but this objective must be divided into categories. A complete financial plan should have financial objectives and related performance objectives in all the following categories: liquidity, profitability, long-term solvency, cash flow adequacy, market strength" (Crosson \& Needles, 2008, p. 658). By using long-term trend analysis of individual financial ratios it is possible to evaluate long-term strategy of the company. ,Management must constantly monitor key financial performance measures, determine the cause of any deviations in the 
measures, and propose corrective actions. Annual measures provide data for longterm trend analysis“" (Crosson \& Needles, 2008, p. 658).

Financial information from aspect of making decisions are necessary to wide range of users. Generally, users of financial information can be divided into two categories, internal and external users. Internal users are those who operate within a company, and consequently they have wider amount of information on disposal. "Internal users of accounting information are managers who plan, organize, and run a business. These include marketing managers, production supervisors, finance directors, and company officers. In running a business, managers must answer many important questions" (Kimmel, et al., 2011, p. 5). On the other side, external users are those stakeholders interested for business operations of a certain company, but are not involved into its business. Those stakeholders mostly use publicly available financial information, mostly presented in form of annual financial statements.

„Financial performance measurement, also called financial statement analysis, uses all the techniques available to show how important items in a company's financial statements relate to the company's financial objectives. Persons with a strong interest in measuring a company's financial performance fall into two groups: (1) a company's top managers, who set and strive to achieve financial performance objectives; middle-level managers of business processes; and lower-level employees who own stock in the company; (2) creditors and investors, as well as customers who have cooperative agreements with the company" (Crosson \& Needles, 2008, p. 658).

„Ratio analysis is used by three main groups: (1) managers, who use ratios to help analyze, control, and thus improve their company's operations; (2) credit analysts, including bank loan officers and bond rating analysts, who analyse ratios to help judge a company's ability to repay its debts; and (3) stock analysts, who are interested in a company's efficiency, risk, and growth prospects. In later chapters, we will look more closely at the basic factors that underlie each ratio“ (Brigham \& Houston, 2009, p. 105).

The research subject includes evaluating how often decision makers in Croatia use accounting information for making business decision. For that purposes, empirical research by using questionnaire had been conducted. The research includes persons responsible for business operations, and consequently making decision, at any level of the company. Empirical research includes question of the importance of knowing typical values of individual financial ratios within the process of making decisions in order to improve quality and transparency of decisions with goal to realization of settled objectives that are consistent with the company's strategy. Related to research question, research objective had been defined and includes examining importance of financial statements and financial statements analysis in business decision process, and investigating possibilities to improve quality of decisions by using typical values of individual financial ratios. In that context, following hypothesis has been developed: 
H1: Information based on accounting data for which exists typical values to determine business quality based on company's characteristics are important for business decision making process.

For business decision making process, different qualitative and quantitative information that are available from all organizational units, and including, available from accounting system, are necessary. "Every investor or other business decision maker, and especially, every manager, to make valid decision, has to have clear perception on accounting terms and concepts" (Belak, 1995, p. 5). Every company has on its disposal basic accounting data that need to be transform into information that will represent basis for business decision-making process. The research includes obtaining information about style in which are information used in Croatia, i.e. weather they are used as the original data available from accounting system, or they are used in form of financial ratios. The research includes question if knowing typical values of individual financial ratios, categorized by business activity or size of companies, would improve quality and increase level of using accounting information within business decision-making process. Frequency of using financial information within business decision-making process depends of several factors as its availability, price, organization, and from the other side, important role has manager himself, and his tendency to use quantitative information and generally his willingness to use modern tools for processing them.

\section{Literature Review}

Previous studies about using accounting information in business decision-making process are focused to three main directions. First, they include research about usefulness of accounting information within process of business decision making. Further, authors researched tendency of using accounting information in process of decision-making, and users of financial information. Eventually, studies included research on quality, availability and form of accounting information for decision-making purposes, and role of accountants in providing those information.

Meter (2006) within his research concluded that the middle management most often uses accounting information in business decision-making process, then higher management, and at the end lower management rarest uses accounting information (Meter, 2006, pp. 528-529). According to research results ,the most often used source of accounting information as a basis for decision making are annual financial statements, then reports from transaction database, and managerial information system and system based on knowledge base" (Meter, 2006, p. 531). Conducted research indicates about importance of accounting system and annual financial statements within the process of decision making at all levels of business operations. Obtained results shows that decision makers "the most often use method of comparing achieved and 
planned values, than relative economic indicators based on financial statements, and at the end comparing business operations of the company with results of competitors, and analyzing variances" (Meter, 2006, p. 532). According to results, managers have tendency to use individual financial ratios for business decision-making purposes.

David (2011) states that assessment of business strategy should be conducted by using quantitative and qualitative criteria. "Quantitative criteria commonly used to evaluate strategies are financial ratios, which strategists use to make three critical comparisons: (1) comparing the firm's performance over different time periods, (2) comparing the firm's performance to competitors', and (3) comparing the firm's performance to industry averages" (David, 2011, p. 293). The most often used instruments for conducting quantitative strategy assessmnet are return on investment (ROI), return on equity (ROE), profit margin, market share, debt to equity, earnings per share, sales and assets growth, and at the end, as a important tool for strategy assessment is financial statements audit (David, 2011, p. 293). Mentioned tools for strategy assessment are individual financial ratios calcualted using data from annual financial statements. „Financial accounting information is designed for decision makers who are not directly involved in the daily management of the company. These users of the information are often external to the company" (Lanen, et al., 2011, p. 6).

Bhushan \& Rai (2004) concludes that for puposes od decision making proces exists different tool as net present value (NPV), internal rate of return (IRR), benefitcost ratio (BCR), total cost of ownership (TCO), payback period, balanced scorecard, economic value added (EVA), return on investment (ROI) (Bhushan \& Rai, 2004, pp. 6-8). For calculating mentioned indicators, directly or indirectly, information from accounting system, i.e. annual financial statements are needed. „It is up to the decision-maker or makers to understand the context, underlying advantages and disadvantages of these tools prior to their deployment in the decision-making process" (Bhushan \& Rai, 2004, p. 6).

Silviu-Virgil (2014) in his study elaborates need for internal and external audit due to fact of development of creative accounting and manipulations of accounting data to provide suitable information for stakeholders. He does not prejudice the usefulness of accounting information within decision-making process, but emphasises need for quality of those information. Due to management role to provide reliable information, author concludes, ,the capitalization of the information in the decisional process is made by the management team, forced to take the best decisions in the shortest period of time, based on information known to be precise, provided by the accounting system“ (Silviu-Virgil, 2014, p. 598). „Accounting represents the core of the informational system, providing most of the information circulating in the economic informational system, and the accountants are the main authors, providing quality information that represent the base for the processing and analysis of information; the users of these information have different interests and they create plans or can make decisions after interpreting accounting information; elaborating correct decisions in 
an optimal period of time is possible only with managers from every hierarchical level, and with access to quality information“ (Silviu-Virgil, 2014, p. 599).

Luminita (2014) also doesn't question usefulness of accounting information and gives detailed information about users of accounting information within decision making process including investors, lenders, business partners (customers and suppliers), the social partners (employees and unions representing them), the government. Author emphasis function of managers as information users. „Managerial team is the one that needs the information in determining the performance of the economic entity but also in making decisions for future activities. When we speak of a managerial team we are talking about a user which can be the manager, the treasurer, the board of directors, the management team, etc., in other words whoever is staying at the helm of economic entity and is giving direction to the development. For them, the interest is to know the information on the operating activity of the entity, on the funding and investment activity in order to make their decisions" (Luminita, 2014, p. 675).

Bebeşelea (2014) also presents detailed list and characteristics of users of accounting information in business decision-making process. Users of accounting information are investors, bank creditors, trade partners (customers and the suppliers), social partners (employees), public power (government), and other extern users (stock analysts). On the other hand, author emphasises „Managers are the main category of users of financial information. Their informational needs are covered, in essence, by the unpublished reports. In general, these reports are drawn based both on information provided by management accounting and on that provided by financial accounting“" (Bebeşelea, 2014, p. 154).

Purwati, et al. (2014) conducted research that provides preliminary evidence on the effect of accounting information content on small and medium-sized companies in making business decisions, particularly investment in Indonesia. „From the test results of the regression can be interpreted that the use of accounting information has a statistically significant influence on performance outcomes teradap effort. It can be interpreted that the factors in the use of accounting information affects business performance outcomes" (Purwati, et al., 2014, p. 70). Authors listed numerous accounting information available from financial statements and accounting system. „The results of the study also concluded that the respondents stated that the information obtained from the financial statements will be used as a basis for decision making loans or investments. Financial statements prepared simply be able to describe the overall condition of the company" (Purwati, et al., 2014, p. 74).

\section{Data and Methodology}

The research about usefulness of accounting data as a quality basis within business decision-making process will include persons responsible for decision making in com- 
panies from Croatia. Element of conducted research is one business subject (company, financial institutions, associations, agencies). In addition, it is important to emphasise that the target group are those subjects that prepare and disclose their annual financial statements. According to Croatian Company Directory in year 2012, 94.847 subjects disclosed their annual financial statements (Hrvatska gospodarska komora, 2014).

Methods used for analysing data, gather by empirical research using questionnaire, are adjusted to types of variables formed through questions and statements. Statistical variables can be presented via two basic attributes including qualitative and quantitative variables. First part of questionnaire consists of basic information about the company, where qualitative attributes for variables are used, i.e. nominal scale. "Nominal scale is given in form of non-numerically dataset, i.e. as a list of terms (attributes, categories, letter codes). Types of nominal variable representing nominal scale can be listed by optional order" (Šošić, 2004, p. 6). Second part of questionnaire consists of questions and statements about using accounting information within business decision-making process. Next to nominal variable, presented by nominal scale, five-level Likert scale is also used. „Ordinal scale or rating scale associates letter codes, symbols or numbers to elements of the variable category in accordance with intensity of measuring characteristic. It is a used to classify and edit elements in accordance with the degree of given attribute“" (Šošić, 2004, pp. 6-7). Likert scale is typical form of ordinal scale.

„The numbers utilized in ordinal scales, however, are really non-quantitative because they indicate only relative positions in an ordered series. Ordinal scales provide no measure of the actual amount or magnitude in absolute terms, only the order of the values. The researcher knows the order, but not the amount of difference between the values" (Hair, et al., 2010, p. 5). Certain authors categorize Likert scale as interval one (Anderson, et al., 2011; Dumičić, et al., 2011; Groebner, et al., 2011). „The scale of measurement for a variable is an interval scale if the data have all the properties of ordinal data and the interval between values is expressed in terms of a fixed unit of measure. Interval data are always numeric“ (Anderson, et al., 2011, p. 6). „If the distance between two data items can be measured on some scale and the data have ordinal properties $(>,<$, or $=$ ) the data are said to be interval data" (Groebner, et al., 2011, p. 22). Main condition to treat Likert scale as interval one, is necessary to determine measurement the same distance between degrees. Nevertheless, other authors categorize Likert scale as ordinal one, what significantly reduce possibilities of statistical data processing (Aczel \& Sounderpandian, 2008; Kemp \& Kemp, 2004; McCrum-Gardner, 2008). Defining type of research variable is important from aspect of defining research methods.

Questions representing nominal variables, i.e. the ones in which answers refers to nominal scale, are analysed by using appropriate technics of graphical representations, contingency tables with the corresponding frequencies and by using appropriate measures of descriptive statistics. Questions in which answers are presented 
through Likert scale were analysed by using graphical representations and appropriate measures of descriptive statistics. To analyse data referring to Likert scale, measures of positional average values, like mod or median, are usually used. Often, to analyse those data, arithmetic mean and standard deviation are also used. Analysing using averages is usual for interval data, but not for ordinal one, and due to that it is important to emphasise that differences between degrees are equal. To test research hypothesis about importance of accounting information in business decision making, appropriate parametric tests are used.

\section{Empirical Results}

Data necessary for conducting the empirical research have been collected by questionnaire, which consist of 25 questions divided into two categories, general information about the company and information about business decision making process and using accounting data for that purposes. All questions but one was mandatory to respond, and one optional question was about personal opinion about using accounting data and technics of financial statements analysis for decision-making purposes. Questions were closed-type, where examinees had to choose one or more of the given answers. Questionnaire has been sent to 2.593 small, medium-sized and large companies of all business activities in accordance with Statistical Classification of Economic Activities 2007 in Croatia, which includes 21 fields of business activities. For sending questionnaire, Google Form was used. In period from 8th April 2014 to 02nd June 2014 total of 320 examinees filled the questionnaire and gave their contribution to the research, representing return rate of $12,34 \%$. Regarding the optional question, 102 from total number of 320 respondents gave their opinion. Sample size is considered representative, and obtained conclusions can be reflected to population.

Table 1: Business activity sectors included into analysis

\begin{tabular}{|l|l|r|r|}
\hline \multicolumn{2}{|c|}{ Business activity } & Number of responses & \% \\
\hline 1 & Industry (B, C, D, E) & 92 & $29 \%$ \\
\hline 2 & Construction (F) & 22 & $7 \%$ \\
\hline 3 & Trade (G) & 133 & $42 \%$ \\
\hline 4 & Non-financial services (H, I, J, L, M, N, S95) & 19 & $6 \%$ \\
\hline 5 & Other & 54 & $17 \%$ \\
\hline \multicolumn{2}{|l|}{ TOTAL } & $\mathbf{3 2 0}$ & $\mathbf{1 0 0 \%}$ \\
\hline
\end{tabular}

Source: Author's calculations

Conducted analysis includes 320 companies from Croatia. Most of companies, precisely 133 or $42 \%$, are doing business operations within Trade (Table 1). After 
that, 92 companies or $29 \%$ are in Industry sector, $7 \%$ (22 companies) are in Construction sector, 6\% (19 companies) are from Non-financial services, and rest of them (54 companies or 17\%) are out of non-financial business economy sector in accordance with Statistical Classification of Economic Activities 2007.

Table 2: Number of employees and size of the company included into analysis

\begin{tabular}{|c|c|c|c|c|}
\hline & & & $\begin{array}{l}\text { Number of } \\
\text { responses }\end{array}$ & $\%$ \\
\hline \multicolumn{5}{|c|}{ Size of the company } \\
\hline 1 & Small company & & 224 & $70 \%$ \\
\hline 2 & Medium-sized company & & 71 & $22 \%$ \\
\hline \multirow[t]{2}{*}{3} & Large company & & 25 & $8 \%$ \\
\hline & & TOTAL & 320 & $100 \%$ \\
\hline \multicolumn{5}{|c|}{ Number of employees } \\
\hline 1 & $<10$ & & 109 & $34 \%$ \\
\hline 2 & $10-50$ & & 118 & $37 \%$ \\
\hline 3 & $51-250$ & & 67 & $21 \%$ \\
\hline \multirow[t]{2}{*}{4} & $>250$ & & 26 & $8 \%$ \\
\hline & & TOTAL & 320 & $100 \%$ \\
\hline
\end{tabular}

Source: Author's calculations

From total number of companies included into the research, $70 \%$ (224) of them are considered as small companies, 22\% (71) medium-sized companies, and 8\% (25) as large companies. Less than 10 employees have 109 (34\%) analysed companies, 118 (37\%) companies employees between 10 and 50 people, 21\% (67) have between 51 and 250 employees, and only 8\% (26) have over 250 employees. It can be concluded that most of the analysed companies (71\%) have up to 50 employees (Table 2).

Most of the examinees operate within top management $(134 ; 42 \%)$ and accounting and finance department $(140,44 \%)$. That brings up the question of reliability of results obtained by the research due the fact that accountants are involved in preparing quantitative financial information. For that purposes, analysis of variances is conducted to determine existence of differences between obtained responses among examinees from different departments. The remaining $14 \%$ of respondents (46) is employed in sales, procurement, marketing, human resources, controlling, administration, production, research \& development, and other (Table 3). 
Table 3: Function of examinees included into analysis

\begin{tabular}{|c|l|r|c|}
\hline \multicolumn{2}{|c|}{ Department } & $\begin{array}{c}\text { Number of } \\
\text { responses }\end{array}$ & $\%$ \\
\hline 1 & Board of directors & 134 & $42 \%$ \\
\hline 2 & Accounting and finance, Controlling & 142 & $44 \%$ \\
\hline 3 & Sale, Procurement, Marketing, Production & 33 & $10 \%$ \\
\hline 4 & Human resources, Administration, Research \& development, Other & 11 & $3 \%$ \\
\hline
\end{tabular}

Source: Author's calculations

Table 4: Type of decisions of examinees included into analysis

\begin{tabular}{|r|l|r|r|}
\hline \multicolumn{2}{|c|}{ Type of decisions } & $\begin{array}{c}\text { Number of } \\
\text { responses }\end{array}$ & \multicolumn{1}{c|}{$\%$} \\
\hline 1 & Strategic decisions & 147 & $46 \%$ \\
\hline 2 & Tactical decisions & 89 & $28 \%$ \\
\hline 3 & Operational decisions & 84 & $26 \%$ \\
\hline \multicolumn{2}{|c|}{ UKUPNO } & $\mathbf{3 2 0}$ & $\mathbf{1 0 0 \%}$ \\
\hline
\end{tabular}

Source: Author's calculations

Majority of respondents usually are involved in making strategic decisions (147; $46 \%)$. Almost equal number of respondents are making tactical $(89 ; 28 \%)$ or operational $(84 ; 26 \%)$ decisions (Table 4$)$. Strategic decisions are related to long-term operations of companies, tactical ones are directed to medium-term period within certain department, and operational are focused to exact activities and projects within the company.

Examinees could select one or more statements regarding purpose and form of using accounting information for business decision making (Table 5). The most often examinees uses accounting information to conduct analysis of realized business results $(203 ; 63 \%)$ and for preparing business plans $(190 ; 59 \%)$. For that purposes they mostly use annual financial statements $(252 ; 79 \%)$. Almost all examinees are conducting comparison with previous accounting periods $(289 ; 90 \%$ from total number of respondents), then comparison with planned values (147; $46 \%$ from total number of respondents). A lesser extent of examinees into analysis includes external factors (59; $16 \%$ from total number of respondents) or comparison with industry $(22 ; 7 \%$ from total number of respondents). 
Table 5: Type and form of accounting information and their purpose within business decision making process

\begin{tabular}{|c|c|c|c|}
\hline & & $\begin{array}{l}\text { NUMBER OF } \\
\text { RESPONDS }\end{array}$ & $\%$ \\
\hline \multicolumn{4}{|c|}{ Within business decision making process, accounting information are usually used for: } \\
\hline SVR1 & Preparing business plans (annual, quarterly, monthly) & 190 & $59 \%$ \\
\hline SVR2 & Conducting analysis of archived business results & 203 & $63 \%$ \\
\hline SVR3 & Conducting comparative analysis related to competitors & 84 & $26 \%$ \\
\hline SVR4 & Reporting board of directors about achieved results of certain department & 132 & $41 \%$ \\
\hline & TOTAL & 609 & I \\
\hline \multicolumn{4}{|c|}{ Form in which examinees uses available accounting information for business decision making purposes: } \\
\hline OBL1 & Raw data from accounting system (absolute numbers) & 105 & $33 \%$ \\
\hline OBL2 & Annual financial statements & 252 & $79 \%$ \\
\hline OBL3 & Financial ratios defined in advance (relative numbers) & 72 & $23 \%$ \\
\hline & TOTAL & 429 & I \\
\hline \multicolumn{4}{|c|}{ Analysis of accounting data is usually conducted with purpose to provide: } \\
\hline ANA1 & Comparison with previous accounting periods & 287 & $90 \%$ \\
\hline ANA2 & Comparison with planned values & 147 & $46 \%$ \\
\hline ANA3 & Comparison with competition & 59 & $18 \%$ \\
\hline ANA4 & Comparison with industry & 22 & $7 \%$ \\
\hline & TOTAL & 515 & l \\
\hline
\end{tabular}

Source: Author's calculations

Conducted empirical research is focused on analysis of determining and evaluating the frequency of using accounting data and annual financial statements within the business decision-making process. Following statements refers to research hypothesis. Examinees did choose one of five degrees using Likert scale, where one represent „Strongly disagree“" and five is „Strongly agree“.

Related to question of frequency of using information available from accounting system within the business decision making process, 140 examinees or 44\% strongly agree, and additional 98 examinees or $31 \%$ agree with that statement, and related to that it can be concluded that they frequently use accounting information for decision making (Table 6). Only 3\% (12) absolutely disagree with statement. Obtained results shows that $75 \%$ of examinees usually use accounting information in business decision making (grades 4 and 5). The greatest number of examinees that uses accounting information (239 from 320 who gave grade 4 or 5) are involved in making strategic decisions (100 examinees), 73 of them are making tactical decisions, and 65 of 239 examinees makes operational decision. According to median value, $50 \%$ of examinees evaluated frequency of using accounting information for decision-making purposes with grade 4 and less, and $50 \%$ of examinees choose grade 4 and greater. 
Mean rating of frequency of using accounting information for making decisions is 4,14 with standard deviation of 0,897 or $21,66 \%$. High average rating is a consequence of the fact that the greatest number of examinees gave the highest grade to the statement.

Table 6: Absolute and relative frequencies for statements included into analysis

\begin{tabular}{|c|c|c|c|c|c|c|}
\hline STATEMENT & 1 & 2 & 3 & 4 & 5 & TOTAL \\
\hline \multirow{2}{*}{$\begin{array}{l}\text { Frequency of using accounting information within business } \\
\text { decision-making process. }\end{array}$} & 1 & 11 & 70 & 98 & 140 & \multirow{2}{*}{320} \\
\hline & $0 \%$ & $3 \%$ & $22 \%$ & $31 \%$ & $44 \%$ & \\
\hline \multirow{2}{*}{$\begin{array}{l}\text { Information available from annual financial statements } \\
\text { (balance sheet and income statement) are usually used within } \\
\text { business decision making process. }\end{array}$} & 5 & 7 & 59 & 88 & 161 & \multirow{2}{*}{320} \\
\hline & $2 \%$ & $2 \%$ & $18 \%$ & $28 \%$ & $50 \%$ & \\
\hline \multirow{2}{*}{$\begin{array}{l}\text { You are familiar with methods of using technics of financial } \\
\text { statements analysis for purposes of evaluating financial } \\
\text { position and business efficiency. }\end{array}$} & 2 & 7 & 36 & 103 & 172 & \multirow{2}{*}{320} \\
\hline & $1 \%$ & $2 \%$ & $11 \%$ & $32 \%$ & $54 \%$ & \\
\hline \multirow{2}{*}{$\begin{array}{l}\text { Existence of the model for evaluating business quality based } \\
\text { on accounting information would ease assessing financial } \\
\text { position and business efficiency. }\end{array}$} & 2 & 11 & 80 & 108 & 119 & \multirow{2}{*}{320} \\
\hline & $1 \%$ & $3 \%$ & $25 \%$ & $34 \%$ & $37 \%$ & \\
\hline \multirow{2}{*}{$\begin{array}{l}\text { Existence of the model for evaluating business quality would } \\
\text { increase frequency of using financial ratios for making } \\
\text { business decisions. }\end{array}$} & 2 & 7 & 71 & 132 & 108 & \multirow{2}{*}{320} \\
\hline & $1 \%$ & $2 \%$ & $22 \%$ & $41 \%$ & $34 \%$ & \\
\hline \multirow{2}{*}{$\begin{array}{l}\text { Existence of typical values of financial ratios would increase } \\
\text { frequency of using them within business decision-making } \\
\text { process. }\end{array}$} & 2 & 6 & 82 & 128 & 102 & \multirow{2}{*}{320} \\
\hline & $1 \%$ & $2 \%$ & $26 \%$ & $40 \%$ & $32 \%$ & \\
\hline
\end{tabular}

1: Strongly disagree

2: Disagree

3: Neither agree nor disagree

4: Agree

5: Strongly agree

Source: Author's calculations

Following statement includes opinion about frequency of using relevant positions from annual financial statements (balance sheet and income statement) for making business decisions. Half of examinees absolutely agrees $(161 ; 50 \%)$ with given statement. Additionally, 28\% (88) examinees agrees with statement, by which it can be concluded that almost $80 \%$ of examinees uses annual financial statements as a basis for making decisions. Even $4 \%$ of examinees do not use annual financial statements within decision-making process. The greatest number of examinees that uses annual financial statements for making decisions (249 from 320 who gave grade 4 or 5) are involved in making strategic decisions (103 examinees), 75 of them are making tactical decisions, and 71 of 249 examinees makes operational decision. Mode rating, i.e. the frequency with the greatest occurrence, is 5. In addition, $50 \%$ of examinees 
evaluated using annual financial statements for decision making with grade 5 and less, and other $50 \%$ of examinees chose grade 5 and greater. Mean rating of using annual financial statements for decision making is 4,23 with standard deviation of 0,93 or $22,01 \%$.

In next question, examinees were asked if they are familiar with methods and technics of financial statements analysis for purposes of evaluating financial position and business efficiency. More than half examinees (172; 54\%) strongly agrees and 103 (32\%) of them agrees with that statement. According to obtained results, it can be concluded that $87 \%$ of examinees are familiar with methods of using technics of financial statements analysis for purposes of evaluating financial position and business efficiency. Even $3 \%$ of examinees disagree with given statement. The mod, i.e. the most frequent grade is 5 which is given by $53,75 \%$ (172) examinees. It can be concluded that quarter of examinees gave grade 4 and less, and three quarters of examinees evaluated the statement with grades 4 and greater. Mean grade of knowing technics of financial statements analysis is 4,36 with standard deviation of 0,815 or $18,68 \%$.

More than $70 \%$ of examinees, strongly agrees $(119 ; 37 \%)$ or agrees $(108 ; 34 \%)$ with statement that existence of the model for evaluating business quality based on accounting information would ease assessing financial position and business efficiency (Table 7). The most frequent grade for that statement is 5, and its mean value is 4,03 with standard deviation of 0,90 or $22,40 \%$. In addition, the greatest number of examinees, strongly agrees $(108 ; 34 \%)$ or agrees $(132 ; 41 \%)$ with statement that existence of the model for evaluating business quality would increase frequency of using financial ratios for making business decisions. It can be concluded that more than $75 \%$ of examinees would increase frequency of using financial ratios for making business decisions in case of existence of the model for evaluating business quality. On average, examinees evaluated that statement with mean value 4,05 with standard deviation of 0,838 or $20,68 \%$. Finally, similar answers were given for statement about increase frequency of using financial ratios for making business decisions in case of knowing their preferable typical values. Average value of that statement is 4,01 with standard deviation of 0,84 or $21,01 \%$, and generally more than $70 \%$ of examinees would increase frequency of using financial ratios in decision making process in case of knowing its typical values. 
Table 7: Descriptive analysis of statements included into analysis

\begin{tabular}{|l|c|c|c|c|c|c|c|c|c|}
\hline \multicolumn{1}{|c|}{ STATEMENT } & n & MEAN & MED & MOD & FM & SUM & Q1 & Q4 & SD \\
\hline $\begin{array}{l}\text { Frequency of using accounting } \\
\text { information within business decision- } \\
\text { making process. }\end{array}$ & 320 & 4,141 & 4 & 5 & 140 & 1325 & 3 & 5 & 0,897 \\
\hline $\begin{array}{l}\text { Information available from annual } \\
\text { financial statements (balance sheet and } \\
\text { income statement) are usually used } \\
\text { within business decision making process. }\end{array}$ & 320 & 4,228 & 5 & 5 & 161 & 1353 & 4 & 5 & 0,931 \\
\hline $\begin{array}{l}\text { You are familiar with methods of using } \\
\text { technics of financial statements analysis } \\
\text { for purposes of evaluating financial } \\
\text { position and business efficiency. }\end{array}$ & 320 & 4,363 & 5 & 5 & 172 & 1396 & 4 & 5 & 0,815 \\
\hline $\begin{array}{l}\text { Existence of the model for evaluating } \\
\text { business quality based on accounting } \\
\text { information would ease assessing } \\
\text { financial position and business efficiency. }\end{array}$ & 320 & 4,034 & 4 & 5 & 119 & 1291 & 3 & 5 & 0,904 \\
\hline $\begin{array}{l}\text { Existence of the model for evaluating } \\
\text { business quality would increase } \\
\text { frequency of using financial ratios for } \\
\text { making business decisions. }\end{array}$ & 320 & 4,053 & 4 & 4 & 132 & 1297 & 4 & 5 & 0,838 \\
\hline $\begin{array}{l}\text { Existence of typical values of financial } \\
\text { ratios would increase frequency of using } \\
\text { them within business decision-making } \\
\text { process. }\end{array}$ & 320 & 4,006 & 4 & 4 & 128 & 1282 & 3 & 5 \\
\hline
\end{tabular}

Source: Author's calculations

To validate research hypothesis, which refers to statement that information based on accounting data for which exists typical values to determine business quality based on company's characteristics are important for business decision making process, appropriate statistical testing were conducted. To obtain results following questions, from the conducted empirical research by using questionnaire, are used:

1. Frequency of using accounting information within business decision-making process. (H1_S1)

2. Information available from annual financial statements (balance sheet and income statement) are usually used within business decision making process. (H1_S2)

3. You are familiar with methods of using technics of financial statements analysis for purposes of evaluating financial position and business efficiency. (H1_S3)

4. Existence of the model for evaluating business quality based on accounting information would ease assessing financial position and business efficiency. (H1_S4)

5. Existence of the model for evaluating business quality would increase frequency of using financial ratios for making business decisions. (H1_S5)

6. Existence of typical values of financial ratios would increase frequency of using them within business decision-making process. (H1_S6) 
Considering the fact that $44 \%$ of examinees operates within accounting and finance department, and they are directly related to accounting data and information, and it is expected that they will use accounting data in a certain form, as a preliminary research, analysis of variance with objective to determine statistically significant differences between responses of examinees operating within various departments, was conducted (Table 8).

Table 8: Evaluating consistency, equality of variances and analysis of variance for chosen statements

\begin{tabular}{|c|c|c|c|c|c|}
\hline & $\begin{array}{c}\text { Cronbach alpha: ,808005 } \\
\text { Standardized alpha: ,809578 }\end{array}$ & $\begin{array}{c}\text { Levene's Test for Homogeneity } \\
\text { of Variances }\end{array}$ & \multicolumn{2}{|c|}{$\begin{array}{c}\text { Analysis of variance } \\
(\mathbf{p}<\mathbf{0 , 0 5})\end{array}$} \\
\hline Variable & Alpha if (deleted) & $\mathbf{F}$ & $\mathbf{p}$ & $\mathbf{F}$ & $\mathbf{p}$ \\
\hline H1_S1 & 0,789571 & 0,311434 & 0,817120 & 5,891 & 0,000636 \\
\hline H1_S2 & 0,800697 & 4,282075 & 0,005556 & 6,343 & 0,000346 \\
\hline H1_S3 & 0,793493 & 2,510595 & 0,058722 & 6,428 & 0,000308 \\
\hline H1_S4 & 0,761661 & 0,819241 & 0,484013 & 1,606 & 0,187970 \\
\hline H1_S5 & 0,753131 & 1,426182 & 0,235061 & 1,504 & 0,213480 \\
\hline H1_S6 & 0,766858 & 0,280602 & 0,839393 & 3,327 & 0,019962 \\
\hline
\end{tabular}

Source: Author's calculations

Preliminary step, before testing, includes evaluating internal consistency of chosen scale. „Cronbach's alpha is a measure of reliability which range between 0 and 1 , where values of 0,60 or 0,70 are considered as lowest limit of acceptability“ (Hair, et al., 2010, p. 92). For variables included into analysis overall Cronbach's alpha is 0,8080 what can be considers as favourable, and accordingly chosen scale of five degrees is considered as reliable and consistent. Cronbach's alpha value for every individual statement is consistent; they range between 0,753 and 0,801 . In order to obtain analysis of differences between answers of examinees from various departments, equality of variances has to be tested. For statements included into analysis, excluding second statement, the calculated $p$-value is greater that theoretical significance level of 5\%, according to what assumption of equality of variances between means can be accepted. Obtained results of the conduced research shows that calculated p-valued for H1_S1, H1_S2, H1_S3 and H1_S6 is lower than theoretical significance level of 5\%, based on what it can be concluded that there exists statistically significant difference between the means of responses for examinees operating within different departments. For statements H1_S4 and H1_S5 statistically significant differences do not exists due the fact that calculated $p$-value is greater than theoretical significance level of 5\%. With respect to obtained results, the research hypothesis is tested separately for examinees operating within board of directors on the one side, and operating within accounting and finance on the other. 
Testing research hypothesis that that information, based on accounting data for which exists typical values to determine business quality, are important for business decision-making process, is conducted by using six statements included in questionnaire, which was evaluated by using Likert scale of 5 degrees. To test research hypothesis one proportion upper tail $Z$ test is used. For that purposes statistical hypothesis is defined where null hypothesis is true when sample proportion is below critical value:

$$
\begin{aligned}
& H_{0} \ldots p \leq p_{0} \\
& H_{1} \ldots p>p_{0}
\end{aligned}
$$

If sample proportion is less than critical value, null hypothesis can be accepted, and opposite, is sample proportion is greater than given critical value, null hypothesis is rejected ${ }^{1}$. Within the research it is assumed that information, based on accounting data for which exists typical values to determine business quality based on company's characteristics, are important for business decision making process if more that $60 \%$ of examinees, taking into account department within they operates, agreed (grade 4) or strongly agreed (grade 5) with chosen statements. Every statement is tested separately (Table 9).

Table 9: Results of one proportion upper tail Z test

\begin{tabular}{|c|c|c|c|c|c|c|}
\hline \multirow{2}{*}{ STATEMENT } & \multicolumn{3}{|c|}{ Board of directors } & \multicolumn{3}{c|}{ Accounting and finance } \\
\cline { 2 - 7 } & & z-value & p-value & & z-value & p-value \\
\hline H1_S1 & 0,69403 & 2,2218 & 0.0131 & 0,82394 & 5,4473 & 0.0000 \\
\hline H1_S2 & 0,70149 & 2,3982 & 0.0082 & 0,87324 & 6,6463 & 0.0001 \\
\hline H1_S4 & 0,85075 & 5,9249 & 0.0000 & 0,91549 & 7,6741 & 0.0002 \\
\hline H1_S5 & 0,72388 & 2,9272 & 0.0017 & 0,71831 & 2,8778 & 0.0020 \\
\hline H1_S6 & 0,76119 & 3,8089 & 0.0001 & 0,75352 & 3,7343 & 0.0001 \\
\hline
\end{tabular}

Source: Author's calculations

According to obtained results of testing proportion by using one proportion upper tail Z test it can be concluded that for every statement, and for both departments, empirical critical value is higher than its theoretical value, i.e. empirical $p$-value is lower that given theoretical significance level of 5\%. Therefore, statistical null hypothesis of the conducted research is rejected, and alternative hypothesis is accepted.

${ }^{1}$ Empirical critical value used for one proportion upper tail $\mathrm{Z}$ test is calculated as:

$$
z=\frac{\hat{p}-p_{0}}{\sigma_{\hat{p}}} ; \sigma_{\hat{p}}=\sqrt{\frac{p_{0}\left(1-p_{0}\right)}{n}}
$$

where $z=$ critical value, $\hat{p}=$ sample proportion, $p_{0}=$ assumed proportion of population, $n=$ sample size (Anderson, et al., 2011, p. 378). 
Despite determined differences between responses of examinees that operate within board of directors and those that operates within accounting and finance department, overall conclusions are the same. According to obtained results, for both categories of examinees, it can be concluded that more than $60 \%$ of examines frequently use accounting information and information available from annual financial statements (balance sheet and income statement) within business decision making process, and that they are familiar with methods of using technics of financial statements analysis for purposes of evaluating financial position and business efficiency. In addition to that, more than $60 \%$ of examinees consider that existence of the model for evaluating business quality based on accounting information would ease assessing financial position and business efficiency, and that existence of the model for evaluating business quality and typical values of financial ratios would increase frequency of using financial ratios for making business decisions. Base on obtained results, research hypothesis that information, based on accounting data for which exists typical values to determine business quality based on company's characteristics, are important for business decision-making process, can be accepted.

\section{Conclusions}

Technics of financial statements analysis are tool usually used for processing original data available within accounting system into logical relationships that gives more comprehensive and concrete information about business operations of the company. Main advantage of financial ratios is their simplicity in calculation and application. Next to individual financial ratios, within the process of evaluating business quality important role has synthetic ratios in form of complex functions used for evaluating business quality, or predicting company's failure. Important question that arise is frequency of using accounting information within business decision-making process. Related to that, empirical research by using questionnaire was conducted including business sector in Croatia. According to results obtained from 320 examinees, information based on accounting data for which exists typical values to determine business quality, based on company's characteristics, are important in business decision-making process.

\section{REFERENCES}

Aczel, A. \& Sounderpandian, J., 2008. Complete Business Statistics. 7th ur. New York City: The Mcgraw-Hill/Irwin Series.

Anderson, D. R., Sweeney, D. J. \& Williams, T. A., 2011. Statistics for Business and Economics. 2nd ur. Mason: South-Western, Cengage Learning. 
Bebeşelea, M., 2014. Accounting Information and its Users. A Study of the Supply and Demand of Accounting Information in Romania. Economics, Management, and Financial Markets, 9(4), pp. 150-157.

Belak, V., 1995. Menadžersko računovodstvo. Zagreb: RRIF.

Belak, V., 1995. Menadžersko računovodstvo. Zagreb: Računovodstvo, revizija i financije.

Bhushan, N. \& Rai, K., 2004. Strategic Decision Making: Applying the Analytic Hierarchy Process. USA: Springer-Verlag London Limited.

Bishop-Clark, C. \& Dietz-Uhler, B., 2012. Engaging in the Scholarship of Teaching and Learning. Sterling, Virginia, USA: Stylus Publishing, LLC.

Brigham, E. F. \& Houston, J. F., 2009. Fundamentals of Financial Management. 12th ur. Mason, OH: South-Western Cengage Learning.

Crosson, S. V. \& Needles, B. E., 2008. Managerial Accounting. 8th ur. Boston: Houghton Mifflin Company.

David, F. R., 2011. Strategic Management. Concepts and Cases. Thirteenth Edition ur. New Jersey: Prentice Hall.

Dečman, N. i dr., 2013. Harmonizacija i standardizacija financijskog izvještavanja malih $i$ srednjih poduzeća. Zagreb: Hrvatska zajednica računovođa i financijskih djelatnika.

Dumičić, K. i dr., 2011. Poslovna statistika. Zagreb: Element d.o.o..

Groebner, D. F., Shannon, P. W., Fry, P. C. \& Smith, K. D., 2011. Business Statistics: A Decision Making Aproach. 8th ur. New Jersey: Pearson Education, Inc..

Groebner, D. F., Shannon, P. W., Fry, P. C. \& Smith, K. D., 2011. Business Statistics: A Decision Making Aproach. 8th ur. New Jersey: Pearson Education, Inc..

Hair, J. F. J., Black, W. C., Babin, B. J. \& Anderson, R. E., 2010. Multivariate Data Analysis, A Global Perspective. 7th ur. New Jersey: Pearson Education, Inc..

Horngren, C. T., Datar, S. M. \& Rajan, M. V., 2012. Cost Accounting: A Managerial Emphasis. 14th ur. Upper Saddle River, New Jersey: Pearson Education, Inc..

Hrvatska gospodarska komora, 2014. Registar poslovnih subjekata. [Mrežno] Available at: http://www1.biznet.hr/HgkWeb/do/extloon;jsessionid=BB15E88B2F53118B54FA6E3E6D17E5F8 [Pokušaj pristupa 07 July 2014].

Kemp, S. M. \& Kemp, S., 2004. Business Statistics Demystified. New York, USA: The McGraw-Hill Company.

Kimmel, P. D., Weygandt, J. J. \& Kieso, D. E., 2011. Accounting Tools for Business Decision Making. 4th ur. Hoboken: John Wiley \& Sons, Inc..

Lanen, W. N., Anderson, S. W. \& Maher, M. W., 2011. Fundamentals of Cost Accounting. 3rd ur. New York: McGraw-Hill/Irwin.

Luminita, R., 2014. Is it Important the Accounting Model Used by the Economic Entity in Making Decisions by the Users of the Information? Points of View. Economic Science Series, 23(1), pp. 669-677.

McCrum-Gardner, E., 2008. Which is the correct statistical test to use?. British Journal of Oral and Maxillofacial Surgery, Svezak 46, p. 38-41.

Meter, M., 2006. Potreba intenzivnijeg korištenja i mogućnosti unapređenja računovodstveno informacijskih sustava u hrvatskim poduzećima. Ekonomski pregled, 57(7-8), pp. 518-545.

Oluić, A., 2008. Kvaliteta računovodstvenih informacijskih sustava u Republici Hrvatskoj. Zbornik Ekonomskog fakulteta u Zagrebu, 6(1), pp. 241-254. 
Purwati, A. S., Suparlinah, I. \& Putri, N. K., 2014. The Use of Accounting Information in the Business Decision Making Process on Small and Medium Enterprises in Banyumas Region, Indonesia. Economy Transdisciplinarity Cognition, 17(2), pp. 63-75.

Silviu-Virgil, C., 2014. The Importance of the Accounting Information for the Decisional Process. Economic Science Series, 23(1), pp. 593-603.

Šošić, I., 2004. Primijenjena statistika. Zagreb: Školska knjiga d.d..

Vitasović, M., 2012. Analiza stanja i doprinosa računovodstvenog informacijskog sustava i sustava upravljanja financijama u segmentu razvoja proračunskog sustava lokalnih jedinica. Ekonomska misao i praksa, 7(2), pp. 563-594.

Žager L., L., 2006. Temeljni pokazatelji analize financijskih izvještaja. Računovodstvo i financije, 52(4), pp. 16-21. 